\title{
The Monthly Malady: A History of Premenstrual Suffering
}

\author{
MICHAEL STOLBERG*
}

In 1931, in a paper presented to the New York Academy of Medicine, Robert T Frank called attention to "a large group of women" who were subject to "premenstrual tension". Their "intense personal suffering", he claimed, far surpassed those "varying degrees of discomfort", which preceded the onset of menstruation in normal women. Restlessness, irritability, a feeling like "jumping out of their skin" combined with various somatic complaints. ${ }^{1}$ In the same year, the psychoanalyst Karen Horney published a paper on "premenstrual mood swings", on the irritability and anxiety, the listlessness, self-depreciation, or even outright depression, which many women experienced in the days preceding menstruation, linking them to strongly rejected fantasies of motherhood. ${ }^{2}$ After World War II, such notions were widely popularized under the new term "premenstrual syndrome" (PMS), which referred more explicitly to the mix of emotional, behavioural and somatic symptoms that Frank had already pointed out. ${ }^{3}$ Since then, PMS has spawned numerous medical and sociological studies and created a flourishing market for advice literature and medical help.

The nature, prevalence and etiology of PMS remain a matter of intense debate. ${ }^{4}$ Various causes have been proposed, ranging from hormone or electrolyte imbalances to the somatization of emotional conflict, but no consensus is in sight, and it has even been argued that there are several distinct premenstrual syndromes. ${ }^{5}$ Definitions tend to be correspondingly general and vague. In current clinical terminology, "PMS" refers to any unspecified periodical somatic, psychological or behavioural disorder

* Michael Stolberg, MD, PhD, Seminar für Geschichte der Medizin der Technischen Universität München, Ismaninger Str. 22, D81675 Munich, Germany.

\footnotetext{
' Robert T Frank, 'The hormonal causes of premenstrual tension', Arch. Neurol. Psychiatry, 1931, 26: 1053-7, pp. 1054-5; Frank had already briefly mentioned the condition in his The female sex hormone, London, Baillière, Tindall and Cox, 1929, p. 236.

${ }^{2}$ Karen Horney, 'Premenstrual tension', in idem, Feminine psychology, London, Routledge and Kegan Paul, 1967, pp. 99-106; the meaning of the German term "Verstimmungen" in the original title ('Die prämenstruellen Verstimmungen', Zeitschrift für psychoanalytische Pädagogik, 1931, 5 (5/6): 1-7) is closer to "negative mood swings".
}

\footnotetext{
${ }^{3}$ Raymond Greene and Katharina Dalton, 'The premenstrual syndrome', Br. med. J., 1953, i: 1007-14; Katharina Dalton, The premenstrual syndrome, London, Heinemann, 1964.

${ }^{4}$ Sharon Golub, Periods: from menarche to menopause, Newbury Park, Sage, 1992, pp. 181-5; Thomas M Johnson, 'Premenstrual syndrome as a western culture-specific disorder' Cult. Med. Psychiatry, 1987, 11: 337-56; John T E Richardson, 'The premenstrual syndrome: a brief history', Soc. Sci. Med., 1995, 41: 761-7.

${ }^{5}$ Psychiatry has recently seen attempts to define a specific Late Luteal Phase Dysphoric Disorder (LLPDD) (Diagnostic and statistical manual of mental disorders. Third editionrevised, Washington, American Psychiatric Association, 1987, pp. 367-9).
} 


\section{Michael Stolberg}

which begins in the days before menstrual bleeding and may or may not end with its onset. ${ }^{6}$

The political debate on PMS is no less controversial, to the point of dividing the feminist movement. ${ }^{7}$ Some have welcomed the attention, sympathy and protection for the suffering women which the recognition of PMS as a medical condition promises. Critics, on the other hand, have portrayed the emergence of PMS as a further step towards the progressive "medicalization" of the female body, in the sense of a "labeling of increasing numbers of normal life events as appropriate for medical 'expertise' and treatment." ${ }^{8}$ In view of its negative ramifications for the social status and career prospects of women, PMS has even been denounced as "a mythical construct disguising oppression". 9

From a more cultural-anthropological perspective, others again have seen premenstrual complaints primarily as a kind of symbolic body language. According to Emily Martin, PMS legitimizes the temporary (and politically ineffective) expression of suppressed irritation, rage or similarly negative, "unfeminine" feelings, which result, in particular, from the status and condition of women in late industrial society. ${ }^{10}$ Thomas M Johnson has even characterized PMS as a "culture-bound disorder" representing core meanings and guiding preoccupations of contemporary Western culture, and, more specifically, the fundamental role conflict between motherhood and productive employment which most women in modern industrial society experience. ${ }^{11}$

Considering the significance and frequency of PMS in modern Western societies, and its paradigmatic value for debates on the "construction" or "framing" of

\footnotetext{
${ }^{6}$ Thus, e.g., Anton M Bergant, et al., 'Ärgerbewältigung und prämenstruelles Syndrom', Wien. Klin. Wochenschr., 1998, 110: 370-5; some would add that the complaints have to be serious enough to interfere with normal activities.

${ }^{7}$ Golub, op. cit., note 4 above, pp. 203-6; Mari Rodin, 'The social construction of the premenstrual syndrome', Soc. Sci. Med., 1992, 35: 49-56; Janet M Stoppard, 'A suitable case for treatment? Premenstrual syndrome and the medicalization of women's bodies', in Dawn $\mathrm{H}$ Currie and Valerie Raoul (eds), The anatomy of gender, Ottawa, Carleton University Press, 1992, pp. 119-29.

${ }^{8}$ Esther Rome, 'Premenstrual Syndrome (PMS) examined through a feminist lens', in Virginia L Olesen and Nancy Fugate Woods (eds), Culture, society, and menstruation, New York, Hemisphere, 1986, pp. 145-57.

9 Jane M Ussher, The psychology of the female body, London and New York, Routledge, 1989, p. 69; Kathy Kendall, 'Sexual difference and the law: premenstrual syndrome as legal defense', in Currie and Raoul (eds), op. cit., note 7 above, pp. 130-46; Jacquelyn Zita, 'The premenstrual syndrome: "dis-easing" the female cycle', in
}

Nancy Tuana (ed.), Feminism and science, Bloomington, Indiana University Press, 1989, pp. 188-210.

${ }^{10}$ Emily Martin, 'Premenstrual syndrome: discipline, work, and anger in late industrial societies', in Thomas Buckley and Alma Gottlieb (eds), Blood magic: the anthropology of menstruation, Berkeley, University of California Press, 1988, pp. 161-81; Martin stresses, at the same time, that women's altered premenstrual mental and physical state "gives them trouble only given a particular kind of industrialized society" (ibid., p. 165, her emphasis); see also Alma Gottlieb, 'American premenstrual syndrome: a mute voice', Anthropology Today, 1988, 4 (6): 10-13; Susan Markens, 'The problematic of "experience": a political and cultural critique of PMS', Gender and Society, 1996, 10: 42-58.

${ }^{11}$ Johnson, op. cit., note 4 above; for a useful introduction into the ongoing debate on this concept see Ronald C Simons and Charles C Hughes (eds), The culture-bound syndromes: folk illnesses of psychiatric and anthropological interest, Dordrecht and Boston, D Reidel, 1985. 


\section{The Monthly Malady}

disease, ${ }^{12}$ it is rather surprising that no serious study of the history of premenstrual suffering across the centuries has been undertaken to date. Indeed, it has been affirmed that no such history exists. The "idea that there are certain characteristic symptoms that are associated with the premenstrual phase of the menstrual cycle", John T E Richardson has recently argued, has "been acknowledged by physicians and the general culture for little more than 60 years". Only "isolated references" could be found in older medical writing. They did not distinguish between premenstrual and menstrual complaints and described them as the pathological condition of a "small minority of women". ${ }^{13}$ Similarly, in Johnson's account of PMS as a culture-bound disorder, its recent appearance and still more recent formalization in Western industrialized societies, serves as a major argument for its uniqueness and specificity to these societies. ${ }^{14}$

Based on a fairly extensive survey of Latin and vernacular medical writing ${ }^{15}$ and drawing on additional evidence from contemporary letter consultations, I want to present a rather different story in this paper. At least from the late Renaissance, I will argue, premenstrual suffering was frequently described as a very common complaint by physicians and women alike. This is far from denying the role of cultural and social influences. Repeatedly, over the centuries, the interpretation and even the very perception and experience of the nature and timing of premenstrual suffering were profoundly reconfigured and transformed. The new meanings of premenstrual suffering which thus emerged cannot be explained as a simple, direct reflection of changing social conditions, however, and of the situation of women, in particular. They were, above all, closely linked to new, evolving notions of menstruation $^{16}$ and the human body, which, in turn, mediated a wide and complex range of cultural and social influences. Before we can successfully tackle the social "construction" of PMS we must therefore describe and examine historical notions of premenstrual suffering in their relationship to changing perceptions of menstruation and the body. This, and no more, is the aim of this paper.

\footnotetext{
${ }^{12}$ I borrow this term from Charles $\mathrm{E}$ Rosenberg, 'Framing disease: illness, society, and history', in C E Rosenberg and J Golden (eds), Framing disease: studies in cultural history, New Brunswick, Rutgers University Press, 1992, pp. xiii-xxvi; in contrast to terms like "social construction" the term "framing" acknowledges that the human body itself, due to its natural properties, may play an important part in this process, even though we have access to these properties only via our culturally and historically contingent modes of experience and interpretation.

${ }^{13}$ Richardson, op. cit., note 4 above, p. 762; ignoring scores of older works on issues like dysmenorrhoea and suppressed menstruation, Mari Rodin even goes so far as to claim that Frank was the first "modern physician to delineate a set of symptoms related to
}

menstruation as a clinical entity" (op. cit., note 7 above, p. 51).

${ }^{14}$ Johnson, op. cit., note 4 above, p. 347.

${ }^{15}$ Richardson, op. cit., note 4 above, bases his claim primarily on the findings of what he calls "a fairly extensive survey of historical and anthropological sources" presented in Oscar Janiger, Ralph Riffenburgh and Ronald Kersh, 'Cross cultural study of premenstrual symptoms', Psychosomatics, 1972, 13: 226-35; this survey does not use a single source preceding Frank's paper, however.

${ }^{16}$ Unfortunately, there is no good and comprehensive modern study on the history of medical ideas on menstruation; the best overview for the pre-modern era is still Hans-Georg Müller-Heß, Die Lehre von der Menstruation vom Beginn der Neuzeit bis zur Begründung der Zellenlehre, Berlin, Ebering, 1938. 


\section{Michael Stolberg}

\section{Catharsis}

Renaissance physicians commonly saw menstruation primarily as a cathartic, a purifying process. Due to her colder and more humid constitution, woman constantly accumulated crude, peccant, excremental matter in her body. In the case of conception, it served as the substrate for the powerful semen, but when no conception occurred, the "expulsive faculty" of the uterus got rid of it via menstruation. If this process was in any way delayed or disturbed, serious and potentially fatal consequences followed. ${ }^{17}$

Premenstrual symptoms were no standard feature in this account but they were mentioned. Thus, according to Jacques Dubois (1478-1555), many women, at the approach of menstruation, "develop a strangulation from the uterus"-presumably due to the local accumulation of peccant matter or to the activation of the "expulsive faculty". But the actual process of excretion was equally burdensome. In fact, according to Dubois, those women whose periods lasted only two days could count their blessings, since all women "suffer and have a heavy body, as long as the afflux of the humour lasts" ${ }^{18}$ Along similar lines, Albertino Bottoni (d. 1598) pointed to an "uneasiness" and a "certain mordacity of the passages" which accompanied the evacuation of the menstrual flux as evidence for the "malignity" and "venomous nature" of the flux. ${ }^{19}$ It was for this reason that woman, during the time that her "menstrual purgation" lasted, largely lost her blooming colour, that her body was weakened and in some way afflicted. ${ }^{20}$

\section{Plethora}

From about 1550, the idea that menstruation purified the female body from accumulating peccant matter was increasingly challenged in academic medicine and by 1650 it was almost exclusively limited to popular medical writing and compilations or re-editions of older works. ${ }^{21}$ Sometimes, in ill-health, nature might use menstruation to evacuate other peccant humours simultaneously but this was only an accidental phenomenon. ${ }^{22} \mathrm{~A}$ healthy woman, the overwhelming majority of physicians now came to believe, had the unique capacity of accumulating a surplus of pure, unspoilt

\footnotetext{
${ }^{17} \mathrm{Cf}$. Giovanni Marinello, Le medicine partenenti alle infermità delle donne, Venice, de'Franceschi Senese, 1563, fols. 86v-87v; Paracelsus, 'Opus paramirum', in idem, Bücher vnd Schrifften, ed. Johannes Huser, Frankfurt, J Wechels Erben, 1603, p. 119; Alessandro Massaria, Practica medica, Lyons, Durand, 1616, pp. 490-1.

${ }^{18}$ Jacques Dubois (Jacobus Sylvius), De mensibus mulierum, et hominis generatione, Paris, Hulpeau, 1555, fol. 2v; if not indicated otherwise, translations from sources other than English are mine.

${ }^{19}$ Albertino Bottoni, De morbis muliebribus, Padua, Meietus, 1585, fol. 12r.

${ }^{20}$ Ibid., fols. $13 \mathrm{r}$ and $15 \mathrm{r}$.
}

\footnotetext{
${ }^{21}$ Neglecting the literature in Latin, the then dominant language of science and medicine, Patricia Crawford in her ground-breaking paper on 'Attitudes to menstruation in seventeenthcentury England', Past and Present, 1981, 91: 47-73, arrives at a somewhat unbalanced account of contemporary medical views and hardly takes any notice of this important change.

${ }_{22}$ Johannes Bohn, Circulus anatomicophysiologicus seu oeconomia corporis animalis, Leipzig, Gleditsch, [1686], p. 258; Daniel Sennert, Practica medicina, 2nd ed., Wittenberg, hered. Merii, 1649, p. 130.
} 


\section{The Monthly Malady}

blood every month, while her more settled life-style might also make her consume less blood than men. ${ }^{23}$ This surplus blood, or maybe just its most valuable part, ${ }^{24}$ nourished the foetus during pregnancy and was redirected towards the breasts as milk during post-partum amenorrhoea. When no conception occurred, this pure excess blood had to be discharged from the body only in order to prevent plethora, i.e. an overloading and excessive dilatation of the vessels and the body in general with blood.

Initially, some authors combined this new concept with traditional Aristotelian ideas of an inferior female body. Although they refuted the idea that menstrual flux was made up of peccant matter or even poisonous, they thought that woman's blood was, sometimes at least, more crude and not as well concocted as that of man. ${ }^{25}$ But increasingly notions of a divinely ordained complementary nature of the male and the female body predominated among academic physicians. ${ }^{26}$ In the seventeenth century, research on the anatomy of the male and female reproductive systems supported this view. As Regnier de Graaf (1641-73) put it: "To men some genital parts are given, and to women others." 27

The menstrual evacuation itself continued, at first, to be explained in terms of Galenic faculties as the work of the "expulsive faculty" which was activated by the increasing uterine blood load.$^{28}$ Later, with the rise of mechanical philosophy, it was commonly interpreted in hydraulic terms. By its sheer volume the accumulating blood dilated the blood vessels, in particular those of the uterus with its low position and good vascular supply, until they could no longer resist the pressure and gave way or burst.

Within the new framework, the significance of menstruation-related complaints changed fundamentally. Among those who still resorted to the notion of an active expulsive faculty of the uterus, opinion was divided. Some authors apparently felt that the mere evacuation of pure natural blood should not cause any major discomfort. ${ }^{29}$ If some women, before their periods, nevertheless suffered from headaches or pain in the abdomen or lower back, from restlessness, heart burn, palpitations

\footnotetext{
${ }^{23}$ Felix Platter, Praxeos medicae opus, quinque libris adornatum, 3rd ed., Basel, König, 1666, p. 525; James Primrose, De mulierum morbis et symptomatis libri quinque, London, Robinson, 1655 , pp. 3-5; Sennert, op. cit., note 22 above, p. 131; Bohn, op. cit., note 22 above, pp. 240-1.

${ }^{24}$ Archibald Pitcairn, The philosophical and mathematical elements of physick, London, Bell and Osborn, 1718, pp. 328-9.

${ }^{25}$ Girolamo Mercuriale, 'De morbis muliebribus', in Gynaeciorum sive de mulierum affectibus commentarii, part 2, Basel, Waldkirch, 1586, pp. 7-195, on pp. 96-9; Luís de Mercado, De mulierum affectionibus libri IIII, Venice, Valgrisius, 1587, p. 16; Massaria, op. cit., note 17 above, pp. 489-91.

${ }^{26}$ See Sennert, op. cit. note 22 above, p. 130 , just to quote a particularly influential authority; cf. Ian Maclean, The Renaissance notion of
}

woman: a study in the fortunes of scholasticism and medical science in European intellectual life, Cambridge University Press, 1980, pp. 33-4.

${ }^{27}$ Regnier de Graaf, De virorum organis generationi inservientibus, Leiden and Rotterdam, Off. Hackiana, 1668, pp. 3-4; similarly Primrose, op. cit., note 23 above, pp. 1-2.

${ }^{28}$ On the "expulsive" or "ekcritic" faculty see Galen, 'Galeni in Hippocratis librum de alimento commentarius II', in C G Kühn (ed.), Claudii Galeni opera omnia, vol. 15, Leipzig, C Cnobloch, 1828 (repr. Hildesheim, Olms, 1965), pp. 229-50, on p. 246.

${ }^{29}$ Sennert, op. cit., note 22 above, p. 133; Primrose, op. cit., note 23 above, pp. 36-40; Roderigo de Castro, De universa muliebrium morborum medicina ... pars prima theorica, 4 th ed., Hamburg, Hirtelius, 1662, pp. 81-2. 


\section{Michael Stolberg}

and fainting, this was, according to James Primrose (c. 1598-1659), due to the peculiar, pathological quality of their blood, namely "above all from a gross, feculent, condensed and clotted and at the same time also sharp blood" ${ }^{30}$

Most academic writers, however, considered premenstrual complaints as normal rather than exceptional. In their view, they were the physiological manifestation of a localized and/or general plethora and the consequent vascular distension and were relieved with the onset of menstruation. Thus, according to Girolamo Mercuriale (1530-1606), "almost all women, during the time when their monthlies are about to flow, are more [than usually] troubled for no other reason than the impetus of the blood which runs out in great quantity". ${ }^{31}$ Before him, Giambattista Da Monte (1498-1551) even gave detailed instructions how physicians could acquire trust and fame by correctly predicting the approach of a woman's periods from the changes in her body. The first indications "that the blood, which wants to flow and to descend to the uterus, begins to move and be agitated" were heaviness, heat in the whole body and a certain lassitude. These were followed by pain and heaviness in the head "due to the many ascending vapours", then by great heat around the spine and the loins, as a result of the repletion and expansion of the vessels. In the end, the veins filled so much that they "also make the whole belly swell, so that some women seem pregnant, because of the accumulation of much matter". The hips hurt, too, as the uterus was pulled downwards. These "signs, which foretell the future period", Da Monte concluded, were "more or less, as the flux must be more or less, according to the diversity of the women's bodies". ${ }^{32}$

From the second half of the seventeenth century, proponents of the new hydraulicmechanist models of menstruation and the body frequently used premenstrual suffering as prime evidence for their theories. To T B Bertrand, writing in 1711, for example, the various symptoms, about which the women complained at the onset of their periods, the prostration and heat of the whole body, the pain in the uterus and the parts around it, especially towards the loins and hips, the headache and the loss of appetite, were as many arguments for plethora. ${ }^{33}$ Similarly, C A F Heumann considered it "a very strong argument" that "when this flux falls upon them, most women feel a more intense heat and pain of the parts close to the uterus, of the loins and in particular of the hips". They also suffered from headaches, tired legs, a languor of the whole body and all that "multitude of symptoms stops on the spot and disappears instantly once the monthlies have started to flow correctly and the blood, which dilates the vessels, opens itself an exit". ${ }^{34}$ Indeed, few eighteenthcentury proponents of the plethora model of menstruation failed at least to mention premenstrual complaints, and some of them explained in great detail how every single symptom followed from the repletion and dilatation of the vessels and the slowing down of the blood circulation. In addition to the symptoms listed by

\footnotetext{
${ }^{30}$ Primrose, op. cit., note 23 above, pp. $36-40$, cit. 36.

${ }^{31}$ Mercuriale, op. cit., note 25 above, p. 99.

${ }^{32}$ Giambattista Da Monte, 'De uterinis affectibus', in Opuscula varia ac praeclara, vol. 2, Basel, Perna, 1558, pp. 704-85, cit. 737-8.
}

\footnotetext{
${ }^{33}$ Thomas B Bertrand, Quaestio medica: An catamenia à plethora?, Prop. Andreas Delaleu, Paris, 1711, p. 5.

${ }^{34} \mathrm{C}$ A F Heumann, De cessante, ob aetatem, mensium fluxu et morbis inde oriundis, Helmstedt, Widow of Schnorr, 1776, pp. XXIV-XXV, XXVI.
} 


\section{The Monthly Malady}

Bertrand and Heumann, swelling and pains in the breast were frequently mentioned, nausea and vomiting due to the vascular distension and stagnation in the stomach, palpitations and sensations of suffocation due to the plethoric overloading of the heart and lungs, and tinnitus, insomnia and bad dreams resulting from the pressure on the particularly soft brain tissue. ${ }^{35}$

A minor but remarkable consequence of the new understanding of menstruation and premenstrual complaints as a passive effect of plethora was that these lost their gender specificity to a certain extent. It was generally accepted that men like women could develop plethora, due to a sanguine constitution, a nutritious diet or lack of physical exercise. And the symptoms which announced haemorrhoidal bleeding as the most frequent means of evacuating plethora in men were said to be so similar to those announcing menstruation that Lazare Rivière (1589-1655) even discussed both together in a single chapter: both were preceded by painful weight and oppression of the back and loins as well as heat, pain and tension in the hypogastric region and stomach disorders. ${ }^{36}$ What was more, this evacuation of superfluous blood from the male body could occur at periodical, monthly intervals. Following Santorio Santorio (1561-1636) some physicians believed, in fact, that all men gained weight every month and then lost it again by some critical evacuation. ${ }^{37}$ If men only observed their bodies attentively, Louis François Lignac (1740-1809) later asserted along similar lines, they would notice that they suffered vague pains or perhaps drowsiness, migraines, and lassitudes on certain days of the month, which announced an evacuation which was to be favoured. ${ }^{38}$

\section{Fermentation}

The major challenge to the predominance of the plethora model in late seventeenthand eighteenth-century medicine was posed by various iatrochemical theories of menstruation. Their proponents explained menstrual bleeding as the result of a fermentation or effervescence of the blood, chyle or serum, locally in the uterus ${ }^{39}$ or

\footnotetext{
${ }^{35}$ Johannes Georg König, De mensibus dolorificis, Altdorf, Meyer, 1709, p. 9; Ernst Wilhelm Westenberg, De catameniis, resp. Johannes Georgius Vette, Harderovici, Sas, 1711, p. 9; John Freind, Emmenologia, London, Cox, 1729, pp. 56-7; Philippus de la Cour, De naturali catameniorum fluxu, Leiden, Verbeek, 1733, p. 16; Gerald Fitzgerald, Traité des maladies de femmes, Paris, Duchesne, 1758, p. 33.

${ }^{36}$ Lazare Rivière, 'Institutionum medicarum libri quinque', in idem, Opera medica universa, Lyons, Anisson and Posuel 1698, pp. 93-4, 'De signis futurae criseos per menses aut haemorrhoïdas'.
}

\footnotetext{
${ }^{37}$ Santorio Santorio, De statica medicina, The Hague, Vlacq, 1657 (orig. 1614), p. 19.

${ }^{38}$ Louis François Lignac, De l'homme et de la femme, considérés physiquement dans l'état du mariage, vol. 3, Lille, Henry, 1774, pp. 497-8.

${ }^{39}$ Walter Charleton, Inquisitio physica de causis catameniorum et uteri rheumatismo, London, Imp. Kettilby, 1685, pp. 91-5, p. 108; François Bayle, 'De causis fluxus menstrui mulierum', in idem, Dissertationes medicae tres, Brugge, van der Meulen, 1678, pp. 3-51.
} 


\section{Michael Stolberg}

in the whole body ${ }^{40}$ As a result of its rapid, violent movement and expansion, the effervescent fluid dilated and eventually overcame the resistance of the uterine vessels, and menstrual bleeding set in. The ultimate cause of this fermentation was variously assigned to a specific menstrual ferment, to the female semen or to the periodical accumulation of non-specific, peccant, fermentable matter in the female body. ${ }^{41}$ Plethora and passive vascular expansion were not deemed a sufficient explanation by the proponents of this model. Rather, reframing older cathartic notions, menstruation was presented as a process by which nature "cleans out" and "purifies" the body, and repeatedly comparisons with the clarification of fermenting fluid in wine-making were evoked. ${ }^{42}$

Premenstrual suffering was frequently described in this context. Indeed, according to Hendrik Snellen, it was so "very rare" and "indeed extraordinary" that such complaints were absent that only one in twenty women showed no such sign. ${ }^{43}$ The accounts of pain, heaviness, heat and tension were similar to those of the plethora model, but fermentation and effervescence were thought to provide a much better explanation for the relatively abrupt onset of symptoms just days before menstruation-symptoms of plethora should have gradually increased over the month. Premenstrual complaints also tended to be described as more violent, reaching particularly dramatic dimensions, when the fermenting menstrual matter was even more impure than usual or its evacuation delayed. Excruciating convulsions and contractions ensued, terrible pains and a suffocating tightening of the chest, until the flux commenced after all. ${ }^{44}$ Particular stress was also put on sensations of heat, burning and itching, which resulted from fermentation and effervescence or from the acrimony of the peccant matter. ${ }^{45}$

Like the plethora model, the fermentation model led its proponents to stress changes in the premenstrual phase. Once bleeding set in, relief could not necessarily be expected immediately, however. Effervescence was then at its maximum and was

\footnotetext{
${ }^{40}$ Regnier de Graaf, De mulierum organis generationi inserventibus tractatus novus, Leiden, Off. Hackiana, 1672, p. 132; Michael Ettmüller, Pratique de médecine spéciale sur les maladies propres des hommes, des femmes et des petits enfans, Lyons, Amaulry, 1691, p. 69; Nicolas Venette, La génération de l'homme, ou tableau de l'amour conjugal, vol. 2, n. p., 1764, pp. 93-4; Hendrik Snellen, Theoriae mechanicae physicomedica delineatio in qua damnosa ejus praecepta ad rationis et experientiae lancem revocantur ac practice emendantur, Leiden, Luchtmans, 1705, pp. 104-5; Snellen thought that fermentation was limited to the serous and lymphatic parts of the blood.

${ }^{41}$ Ettmüller, op. cit., note 40 above, p. 69 , traced the ferment to the ovaries and the uterus, for example; Venette, op. cit., note 40 above, $p$. 99, wrote of "spermatic vapours"; Charles
}

Barbeyrac, Traités nouveaux de médecine, Lyons, Certe, 1722, p. 206, assumed a particular ferment in the blood.

${ }^{42}$ Carlo Musitano, De morbis mulierum tractatus, Coligny, Choüet, et al. 1709, pp. 47 (cit.), 55; some thought, however, that menstrual blood was originally pure and acquired a corrupt nature only due to its long stasis in the uterus.

${ }^{43}$ Snellen, op. cit., note 40 above, p. 104.

${ }^{44}$ Ettmüller, op. cit., note 40 above, pp. 102-3.

${ }^{45}$ Charleton, op. cit., note 39 above, p. 91; Musitano, op. cit., note 42 above, p. 56; Bayle, op. cit., note 39 above, p. 23; Cornelis Stalpart vander Wiel, Observationum rariorum medicarum anatomicarum chirurgicarum centuriae posterioris pars prior, Leiden, a Kerkhem, 1727, pp. 232-3; Martin Lister, Dissertatio de humoribus, London, Bowyer, 1709, pp. 420, 442. 


\section{The Monthly Malady}

bound to continue at least for a while. ${ }^{46}$ Indeed, fever or "feverish" sensations as characteristic signs of menstrual effervescence and increased blood circulation were sometimes described as ceasing with the end of the period only. ${ }^{47}$

Not all premenstrual complaints were directly traced back to the effects of fermentation and acrimony. Leading proponents of the fermentation model also underlined the outstanding "sympathetic" influence of the uterus on the rest of the female body, a feature which was to gain even greater prominence in the following period. According to François Bayle (1622-1709) this "sympathy" had its basis above all in the nerves. Due to their influence "the breasts swell up and turn harder, when the menstrual purgation is near and the uterine fervour begins" ${ }^{48}$ Similarly, Walter Charleton (1619-1707) explained the heaviness in the head, the nausea, the disgust of food, the weakness of the legs, the pain in the loins, etc. which "often befall the menstruating women near the beginning of the flux" primarily as a nervous phenomenon. ${ }^{49}$

\section{The Irritable Uterus}

In the course of the eighteenth century, traditional iatrochemistry disappeared almost completely from academic medicine, and purely mechanist notions of the human body were increasingly called in question as too reductionist. The living body came to be seen as fundamentally different from inanimate matter. Attention began to shift towards the specific vital properties, functions and reactive faculties of the individual organs and their fibres. ${ }^{50}$ Notions of menstruation as a relief from plethora continued to prevail but, in accordance with the new concepts, menstruation was increasingly reframed into an active process. In the early eighteenth century, Georg Ernst Stahl (1660-1734) and his followers attributed this activity to the human soul or nature in general. Forcing the fibres into tonic contraction, they moved the blood at periodical intervals from the periphery towards the uterus and excreted it. ${ }^{51}$ Women in the days before their periods-like men before their piles started bleedingtherefore suffered from more than simply local pain, in their abdomen, back or hip, which ceased rapidly when the blood was excreted. With no necessity to invoke nervous "sympathy", premenstrual pain could also be found far away from the

\footnotetext{
${ }^{46}$ Often terms like "instante fluxu" or "sub initium purgationis" were used, which can, in principle, refer not only to an event which is near but also to one which has just begun; it follows from the logic of the model, however, that fermentation had to begin before the actual flux set in.

${ }^{47}$ Venette, op. cit., note 40 above, p. 100 ; Ettmüller, op. cit., note 40 above, p. 70 ; notions of fever and increased blood circulation were then closely linked; cf. Herman Boerhaave, Aphorisms, concerning the knowledge and cure of diseases, London, Bettesworth and Hitch, 1735, p. 139.
}

\footnotetext{
${ }^{48}$ François Bayle, 'De consensu variarum corporis partium cum utero', in Bayle, op. cit., note 39 above, p. 72; the nervous influence, he thought, was exerted via the relaxation and constriction of the affluent and the effluent vessels respectively.

${ }^{49}$ Charleton, op. cit., note 39 above, pp. 73-5.

${ }^{50}$ For a useful analysis see François

Duchesneau, La physiologie des lumières:

Empirisme, modèles et théories, The Hague, Nijhoff, 1982.

${ }^{51}$ Georg Ernst Stahl, Proempticon inaugurale de fluxu muliebris, quatenus menstrui causa, HalleMagdeburg, 1702.
} 


\section{Michael Stolberg}

uterus, for example in the head or the arm, when nature contracted the muscles and fibres of those parts in order to move the blood towards the uterus. ${ }^{52}$

The Stahlian view as well as persisting mechanist notions were increasingly replaced, from the mid-eighteenth century, by the new models developed by Théophile de Bordeu (1722-1776) and the Montpellier school of vitalism. Menstruation came to be considered as a specific, vital function of the uterus. It was described in terms of a periodical activation, an "erection", an "orgasm" of the uterus which attracted the blood for excretion, or as an active glandular secretion. ${ }^{53}$ Later, from the $1830 \mathrm{~s}$ and $1840 \mathrm{~s}$, attention also focused on the role of the ovaries. Some understood the maturation and rupture of the follicle and menstrual bleeding as two aspects of a more general process. Others considered menstruation no more than a secondary effect of ovarian changes. E F W Pflüger (1829-1910), for example, whose ideas dominated debates in the late nineteenth century, explained menstruation as the result of a nervous reflex, triggered by the irritation of the ovary by follicular expansion. ${ }^{54}$

The activation of the uterus, the synergistic impact of the ovarian phenomena or the sheer accumulation of blood, as modified versions of the plethora model continued to hold ${ }^{55}$ all had one effect in common: they stimulated and irritated the sensitive uterus. ${ }^{56}$ And the uterus, in turn, due to its overwhelming sympathetic influence on the nervous system, subjected the woman to its unrelenting tyranny. Sacrificing her health for the procreation of the species, woman throughout her reproductive years

\footnotetext{
52 Johann Storch, Von Kranckheiten der Weiber, IIter Band, Darinnen vornehmlich solche Casus, Welche den Jungfern-Stand betreffen, Gotha, Mevius, 1748, pp. 246-8.

${ }^{53}$ Théophile de Bordeu, 'Recherches anatomiques sur la position des glandes, et sur leur action', in idem, Oeuvres complètes, vol. 1, Paris, Caille and Ravier, 1818 (orig. 1752), pp. 45-208, here pp. 190-4; Nicolaus Salmon, Dissertatio physiologica de fluxu menstruo, Montpellier, Martel, 1745, p. 3; other leading proponents of this model were Jean B Jeannet des Longrois, Conseils aux femmes de quarante ans, Paris, Méquignon, 1787, p. 41; Philippe Pinel, Nosographie philosophique, ou la méthode de l'analyse appliquée a la médecine, vol. 1, Paris, Richard, Caille and Ravier, an VII (1798), pp. 273-4; Joseph-Marie-Joachim Vigarous, Cours élémentaire de maladies des femmes, ou essai sur une nouvelle méthode pour étudier et pour classer les maladies de ce sexe, vol. 1, Paris, Crapelet for Deterville, an X (1801), p. 71; Alexandre Surun, Théorie de la menstruation fondée sur les caractères naturels de la vie, des organes, et particulièrement de l'action nerveuse, Paris, Croullebois, 1819; Édouard Dauby, Quelques considérations sur la menstruation dans ses rapports avec la folie, Paris, A Parent, 1866, pp. 12-13.
}

\footnotetext{
${ }^{54}$ Augustin Nicholas Gendrin, Traité philosophique de médecine pratique, vol. 2, Paris, Germer Baillière, 1839, pp. 6-53; Edward John Tilt, On diseases of women and ovarian inflammation in relation to morbid menstruation, sterility, pelvic tumours, and affections of the $w o m b$, 2nd ed., London, Churchill, 1853, p. 23; on Pflüger, see Hans H Simmer, 'Experimentelle Prüfungen der Pflügerschen Reflexhypothese der Menstruation im späten 19. Jahrhundert', Clio Medica, 1979/80, 14: 235-54.

${ }_{55}$ Following Jean Astruc, Traité des maladies des femmes, vol. 1, Lyons, Libraries associés, 1765 , pp. 18-35, various authors held that menstruation resulted from a local plethora only, which was presumably caused by the position and the specific vascular anatomy of the uterus; cf., for example, Franz Anton Mai, Fata ac incommoda ex menstruis naturae lege tandem cessantibus oriunda, prop. F J Vanderlinde, Heidelberg, Wiesen, 1789, p. 3.

${ }^{56}$ Bordeu, op. cit., note 53 above, p. 194; verbatim also in Vigarous, op. cit., note 53 above, p. 86; similarly Constant Saucerotte, Nouveaux conseils aux femmes, sur l'áge prétendu critique, ou conduite à tenir lors de la cessation des règles, 2nd ed., Paris, Auger-Méquigon and Delaunay, 1829, p. 47.
} 


\section{The Monthly Malady}

was condemned to suffer a "monthly indisposition", 57 a condition which "approaches more or less a state of disease" ${ }^{58}$ Due to the "excessive sensitivity and mobility" of the uterus and the nervous system during these days, the "slightest accident" was sufficient to open a vicious circle. Any irritation and consequent contraction of the uterine fibres delayed menstruation, causing further irritation and disturbance. ${ }^{59}$ The term "menostasis" was coined for this condition, which, according to the Dictionaire [sic] des sciences médicales of 1819 , was characterized by uterine colics, beginning about twelve to fifteen hours before the onset of bleeding, and was more common than any other female affliction. ${ }^{60}$

Some of the consequences of the menstrual effort and irritation could be directly observed from the outside. The women showed an air of suffering and languor, with dark circles around the eyes. The wrinkles in their faces were more pronounced, the eyes lost their lustre. ${ }^{61}$ Among the local symptoms a "sense of fullness in the pelvic region, pains in the loins and in the ovarian regions" remained typical, a feeling of heaviness, pulling and heat in the belly or lower back, attesting to the increased afflux of blood and the turgescence of the tissue. ${ }^{62}$ But the most characteristic complaint was the intense uterine colics which many women were said to experience. They preceded and/or accompanied menstruation and reflected the response of the contractile uterine fibres to the menstrual activation and/or irritation. ${ }^{63}$ Indeed, the "expulsive character" of these colics was so marked that physicians frequently described them as much like the "bearing-down pains" of women in labour. It was as if the uterus tried "to free itself" from its burden. ${ }^{64}$ "Vaporous" and hysterical women were at particular risk, and some of them could literally feel the uterus moving. ${ }^{65}$

As to the rest of the body, many symptoms which featured in older accounts recurred, though their primary cause was no longer a surplus of blood or peccant matter in the body but the influence of the activated and/or irritated uterus on the nervous system. Facial flushing, sudden sensations of heat or cold, headaches and migraines, nose bleeding, the vomiting of blood, fainting, palpitations and bad dreams

\footnotetext{
${ }^{57}$ John Leake, Medical instructions towards the prevention and cure of chronic diseases peculiar to women, 4th ed., London, Baldwin, 1777, p. 49.

${ }^{58}$ Pierre Roussel, Système physique et moral de la femme, Paris, Vincent, 1775, p. 207.

${ }^{59}$ Vigarous, op. cit., note 53 above, pp. 93 (cit.), 142-51.

${ }^{60}$ François Victor Merat, 'Ménostasie', in Dictionaire [sic] des sciences médicales, Paris, Panckoucke, 1819 (Microfiche-Reprint Erlangen, Fischer, 1993), vol. 32, p. 374; Johannes H D Effler, De menstruatione vitiosa, MD thesis, Göttingen, Off. Grapiana, 1800, p. 27, refers to "menostasia" in the context of a total suppression.

${ }^{61}$ Charles François Menville de Ponsan, L'âge critique chez les femmes, Paris, Baillière, 1840, pp. 70-1; similarly Johannes David Beerstecher, De fluxu menstruorum doloroso, Duisburg, Widow of
}

Benthon, 1784, p. 9.

${ }^{62}$ Tilt, op. cit., note 54 above, p. 162; Astruc, op. cit., note 55 above, p. 17; Mai, op. cit., note 55 above, p. 3; Salmon, op. cit., note 53 above, p. 26; Charles Louis de Jaucourt, 'Règles, maladies des', in Encyclopédie ou dictionnaire raisonné des sciences, des arts et des métiers, Neufchastel, Faulche, 1765, vol. 14, pp. 26-8; Gendrin, op. cit., note 54 above, pp. 7-8.

${ }^{63}$ Bordeu, op. cit., note 53 above, p. 194; Samuel Auguste Tissot, Advice to the people in general with regard to their health, London, Becket and de Hondt, 1765, pp. 358-9; similarly John Fothergill, 'Of the management proper at the cessation of the menses', Medical Observations and Inquiries, 1774, 5: 160-86, pp. 185-6.

${ }^{64}$ Beerstecher, op. cit., note 61 above, p. 11; Tilt, op. cit., note 54 above, p. 162.

${ }^{65}$ Bordeu, op. cit., note 53, p. 194. 


\section{Michael Stolberg}

could equally well be interpreted as the consequence of a nervous overstimulation of the vascular system. ${ }^{66}$ Spasmodic muscular contractions of the arms and legs, of the abdominal muscles, of the intestines, the diaphragm or the throat bore direct witness to the nervous irritation. ${ }^{67}$

Among all the parts of the body the one which was deemed most sensitive to irritation and overstimulation was the brain, especially in women. While earlier physicians like Friedrich Hoffmann (1660-1742) had already reported individual cases of periodical emotional and mental disturbances linked to menstruation, ${ }^{68}$ these now came to rank among its characteristic effects. Twenty per cent of all women, according to a survey by Alexandre J F Brierre de Boismont (1797-1881), experienced serious psychological troubles in relation with menstruation. ${ }^{69}$ Even women who suffered no other noticeable complaints at the time of their period, Samuel Auguste Tissot (1728-1797) remarked, were "more delicate" and "more easily affected by the passions of the mind". ${ }^{70}$ Women at this time, others confirmed, suffered from a "nervous overexcitation", sensory disturbance, "mood changes" and "vapours". Their intellectual capacities were diminished and they were subject to very peculiar caprices, to whims of character and taste. ${ }^{71}$ Some became dreamy, weak and sleepy, others were sad or depressed, had involuntary fits of weeping, or suffered from anxiety. ${ }^{72}$ In extreme cases, a "menstrual folly" or "menstrual psychosis" or the periodical deterioration of a pre-existing epilepsy, mania or hysteria could be observed. ${ }^{73}$ For this reason, physicians, and the forensic psychiatrist in particular, were well advised to always inquire about the woman's menstruation. ${ }^{74}$

Most frequently, however, women became "irritable" and impatient, "difficult to

\footnotetext{
${ }^{66}$ Astruc, op. cit., note 55 above, p. 18 ; Jaucourt, op. cit., note 62 above; Tissot, op. cit., note 63 above, p. 359; Gendrin, op. cit., note 54 above, p. 10; Pinel op. cit., note 53 above, pp. 623-4; J A Henri Depaul and Alexandre Guéniot, 'Menstruation' in Dictionnaire encyclopédique des sciences médicales, second series, Paris, Masson, 1877 (microfiche-reprint, Erlangen, Fischer, 1994), vol. 2 , pp. 678-736.

${ }^{67}$ Bordeu, op. cit., note 53 above, p. 194; Mai, op. cit., note 55 above, p. 3.; Joseph Capuron, Traité des maladies des femmes, depuis la puberté jusqu'à l'âge critique inclusivement, Paris, Crapelet, 1812, p. 20.

${ }^{68} \mathrm{Cf}$. Friedrich Hoffmann, $A$ system of the practice of medicine, London, Murray and Johnson, 1783 , vol. 2 , pp. $60-1$, on period-related hypochondriasis, with anger, fear, despair and strange imaginations as occasional symptoms.

${ }^{69}$ Alexandre J F Brierre de Boismont, De la menstruation, considérée dans ses rapports physiologiques et pathologiques, Paris, Baillière, 1842; the figure was based on interviews with 223 women.

${ }^{70}$ Tissot, op. cit., note 63 above, p. 360 .

${ }^{71}$ Menville de Ponsan, op. cit., note 61 above, p. 70; Henri Taguet, De l'influence de la menstruation sur le système nerveux, MD thesis,
}

Paris, Parent, 1872, pp. 13-14; Dauby, op. cit., note 53 above, p. 32; Brierre de Boismont, op. cit., note 69 above, p. 95 ; some women also became more gentle and amiable.

${ }_{72}$ Merat, op. cit., note 60 above; Beerstecher, op. cit., note 61 above, p. 9; Brierre de Boismont, op. cit., note 69 above pp. 95-6; Capuron, op. cit., note 67 above, p. 20.

${ }^{73}$ J E D Esquirol, Des maladies mentales considérées sous les rapports médical, hygiénique et médico-légal, Paris, Baillière, 1838, vol. 1, pp. 69-70; Taguet, op. cit., note 71 above; $\mathrm{H}$ Dagonet, Traité des maladies mentales, Paris, Baillière et fils, 1894, p. 157; Richard von KrafftEbing, Psychosis menstrualis. Eine klinischforensische Studie, Stuttgart, Enke, 1902; Menville de Ponsan, op. cit., note 61 above, p. 70; François Émmanuel Fodéré, Traité du délire, appliqué à la médecine, à la morale et à la législation, Paris, Croullebois, 1817, vol. 1, pp. 517,553 ; Gendrin, op. cit., note 54 above, pp. 10-11.

${ }^{74}$ Brierre de Boismoint, op. cit., note 69 above, p. 95; Ambroise Tardieu, Étude médicolégale sur la folie, Paris, Baillière et fils, 1872, p. 80. 


\section{The Monthly Malady}

live with", annoyed "at the slightest motive" ${ }^{75}$ In the days preceding their period, Eduard Krieger (1816-1870) affirmed, they were ready to "jump out of their skins" at the slightest provocation, such as the slamming of a door. Some had regular fits of rage which ceased only "when a fairly abundant menstrual flux has appeared", while the women themselves were often unaware of this change and denied the bad state of their nerves, their "nervous irritation" ${ }^{76}$ The women thus temporarily put aside accepted norms of adequate female behaviour, the "dissimulation" and the mastery of their will and passions, which, according to Jean B Jeannet des Longrois, they were brought up to, and the need "to put up a mask" in society. ${ }^{77}$ Along similar lines, unsuspected intellectual abilities could emerge, as in the case of a pharmacist's wife, described by Brierre de Boismont, who, to her own amazement and that of her friends, wrote poetry and harangues when her periods arrived, and conversed "about subjects which have no relation with her ordinary habits", such as history, geography and politics. ${ }^{78}$

The common observation that some women suffered more from premenstrual and menstrual disorders than others, had already prompted detailed discussions in older writing. Lack of physical exercise, copious, nutritious food, and childlessness were identified as particularly potent predisposing factors. In the late eighteenth century, this debate intensified, taking up ideas from a much wider contemporary critique of the unhealthy, "unnatural", excessively refined and "effeminate" life-style of the urban upper classes. From this perspective, premenstrual and menstrual disorders and indeed, as some argued, menstruation itself, ${ }^{79}$ were explained as largely manmade and self-inflicted. The affluent city women acquired an artificial state of plethora due to their idle life-style and copious food. And they exposed their body and nervous system to constant overstimulation and irritation from spicy dishes, coffee, liqueurs and tobacco, from an excessive and mostly nocturnal sociability, from lascivious novels, music, theatre and painting. The result was a marked contrast between the numerous urban women, in whom, as Lignac wrote "every month, terrifying colics, horrendous convulsions precede the appearance of the periods" and the women of the countryside, "where nature still preserves her rights" and where "one only rarely finds the accidents which precede or accompany the periodical flow". 80

As to the temporal relationship between the symptoms and menstruation, the uterus obviously had to be activated and/or filled with irritating blood before bleeding started, with all corresponding effects on the nerves and the body, and many authors, as some of the passages just quoted already suggest, attributed symptoms specifically p. 95 .

${ }^{75}$ Brierre de Boismont, op. cit., note 69 above,

${ }^{76}$ Eduard Krieger, Die Menstruation. Eine gynäkologische Studie, Berlin, Hirschwald, 1869, pp. 82-3, p. 86.

${ }^{77}$ Jeannet des Longrois, op. cit., note 53 above, pp. 10-11.

${ }^{78}$ Brierre de Boismont, op. cit., note 69 above, p. 97; according to some authors sexual desire also increased around the time of menstruation.

\footnotetext{
${ }^{79}$ Roussel, op. cit., note 58 above.

${ }^{80}$ Lignac op. cit., note 38 above, pp. $479-80$; similarly Astruc, op. cit., note 55 above, p. 17; see also, referring primarily to complaints during the periods, Alexander Hamilton, $A$ treatise on the management of female complaints and of children in early infancy, Edinburgh, Hill, and London, Murray, 1792, p. 131; Taguet, op. cit., note 71 above, p. 11 .
} 


\section{Michael Stolberg}

to the premenstrual phase. ${ }^{81}$ This did not preclude, however, the symptoms ceasing only with the end of the period, when "the work and the laborious efforts of eruption" were largely or completely over. ${ }^{82}$ As in the fermentation model, the transition from the premenstrual to the menstrual phase lost some of its importance in this respect.

\section{Hormones and Psychology}

In the late nineteenth century, the medical gaze on female sex physiology shifted further away from local uterine and ovarian changes towards the periodical, wavelike changes which the whole female organism underwent throughout the menstrual cycle. Experiments with ovarian extracts and transplants around 1900, and the identification and isolation of sex hormones in the 1920s then provided crucial support for a new, endocrinological interpretation of menstruation, raising high hopes for a different, more specific treatment of menstrual disorders with female sex hormone. By the early 1930s scientists and pharmaceutical companies formed a powerful alliance to promote the new substances as a cure-for-all in all kinds of female ailments. ${ }^{83}$

In their seminal papers on premenstrual "tension" and "mood swings", Frank and Horney explicitly referred to the new sex endocrinology, of which Frank was, in fact, an outstanding protagonist. ${ }^{84}$ Yet it would be too simple to see theirs as just another attempt to further extend the realm in which the new substances could be fruitfully and profitably applied. ${ }^{85}$ Frank was openly sceptical about the therapeutic value of giving sex hormones in these cases-he attributed them to raised levels of sex hormone which obviously could not be corrected by artificial substitution. And Horney went on to offer a psychoanalytical explanation which was clearly at odds with a purely hormonal account. Several other factors combined to direct attention to premenstrual psychological suffering at that historical juncture. First, with growing numbers of women in the workforce, the potential negative effects of menstruation in general, on the physical as well as the mental work-performance, attracted increasing interest, an

\footnotetext{
${ }^{81}$ Further examples are J Henry Bennet, On healthy and morbid menstruation, Lancet, 1852 , i: $35-6,65-8,215-17,328-9,353-4$, here pp. 65-6; S V Kaiser, Ein Regulator der weiblichen Gesundheit oder Bleichsucht, Regelstörungen und Weißfluß der Mädchen, Jüngfrauen und Frauen nach ihrem Wesen, ihren Ursachen und ihrer homöopathischen Heilung, Delitzsch, Pabst, 1868, p. 13.

${ }^{82}$ Pinel, op. cit., note 53 above, pp. 623-4.

${ }^{83} \mathrm{Cf}$. Nelly Oudshoorn, Beyond the natural body: an archaeology of sex hormones, New York and London, Routledge, 1994; for a useful
}

\author{
contemporary survey see William P Graves, \\ Fer:ale sex hormonology: a review, Philadelphia \\ and London, Saunders, 1931. \\ ${ }^{84}$ Frank, Female sex hormone, op. cit., note 1 \\ above; Charles Mazer and Leopold Goldstein, \\ Clinical endocrinology of the female, Philadelphia \\ and London, Saunders, 1932. \\ ${ }^{85}$ This goes against Oudshoorn's unsatisfying \\ explanation in an otherwise very recommendable \\ study (Oudshoorn, op. cit., note 83 above, p. 96).
}




\section{The Monthly Malady}

interest which was to grow further in World War II. ${ }^{86}$ Second, there was a long-term trend, at least from the late eighteenth century, among physicians and the general public alike, towards an increasing awareness of what we would now consider the purely "psychological" aspects of human life. No longer did emotional distress and mood changes have to be communicated and interpreted primarily in somatic terms, like "vapours" and "nerves" or, more recently, "neurasthenia" in order for a patient to gain recognition as a sufferer, a worthy patient. ${ }^{87}$ Third, decades before physicians told them that this was what they should expect, growing numbers of women seem to have confronted their physicians specifically with mostly premenstrual psychological complaints. According to a large survey published by Maria Tobler in 1905, 524 (51.4 per cent) of the 1020 women she interviewed experienced some kind of period-related psychological disorder and in 428 of these cases (81.7 per cent) it affected the premenstrual phase. Even where psychological complaints combined with somatic ones, they commonly started earlier. ${ }^{88}$

By the 1930s, the link was firmly established. Horney explicitly acknowledged that the premenstrual mood swings she described were well known. ${ }^{89}$ In the discussion which followed Frank's paper of 1931, other physicians also immediately agreed that "premenstrual tension" was common, that "depression and emotional tension" in this period were often seen. ${ }^{90}$ This suggests that Horney and Frank may have primarily reacted to a changing pattern in the complaints which they, like many physicians, observed among their female patients. The new endocrinological model, better even than the previous "wave theory" of menstruation, then added scientific credibility to these accounts. The cyclical changes in sex-hormone levels provided a plausible explanation for complaints in any part of the body at any point of the menstrual cycle, and not just during menstruation itself.

\section{Female Experiences}

First-hand accounts of female experiences of premenstrual discomfort are unfortunately quite rare before the twentieth century. Even those educated women who

\footnotetext{
${ }^{86}$ Mary Putnam Jacobi, The question of rest for women during menstruation, New York, Putnam's Sons, 1877; Josef von Jaworski, 'Ueber den Einfluss der Menstruation auf die neuropsychische Sphäre der Frau', Wien. klin. Wochenschr. 1910, 23: 1641-3; Georgene H Seward, 'Psychological effects of the menstrual cycle on women workers', Psychol. Bull., 1944, 41: 90-102; Seward (ibid., p. 99) concluded that recognition "of the increasing need for women workers both by industry and by the women themselves is causing a rapid shift in menstrual mores and a realization that female biology in no way makes for inferiority."

${ }^{87}$ A comparison of patient letters from the late eighteenth and the mid-nineteenth centuries (see below) is very revealing in this respect; for the "language of the nerves" see George Rousseau, 'Cultural history in a new key:
}

towards a semiotics of the nerve', in Joan H Pittock and Andrew Wear (eds), Interpretation and cultural history, Basingstoke and London, Macmillan, 1991, pp. 25-81.

${ }^{88}$ Maria Tobler, 'Ueber den Einfluss der Menstruation auf den Gesamtorganismus der Frau. Auf Grund von 1000 [sic] Beobachtungen', Monatsschrift für Geburtshilfe und Gynäkologie, 1905, 22: 1-45; in a further 45 cases with exclusively "local" complaints the premenstrual or intramenstrual timing is not indicated; for an English summary, see Emil Novak, Menstruation and its disorders, New York and London, Appleton, 1921, pp. 82-4.

${ }^{89}$ Though Richardson (op. cit., note 4 above, p. 761) wrongly denies this; see Horney, op. cit., note 2 above.

${ }^{90}$ Frank, 'Premenstrual tension', op. cit., note 1 above, p. 1057. 


\section{Michael Stolberg}

maintained a fairly extensive private correspondence or who wrote autobiographies only rarely mentioned menstruation, not to speak of premenstrual suffering. For the period from the late seventeenth to the early nineteenth centuries, such issues were quite frequently addressed in female patient letters, however. Consultation by letter was a widespread practice among the middle and upper classes of that time. Sometimes the local physician wrote the letter but in many cases the patients or their relatives personally asked for advice. ${ }^{91}$ Since the distant physician's diagnosis and therapy relied exclusively on written communication, a rather exhaustive account had to be given, which included any alterations of the physical state which might help him understand the etiology and nature of the disease. Changes in the quality, quantity or pattern of menstruation ranked highly in this respect. The letters thus provide us with unique insights into female (and male) lay perceptions of menstruation and, to a more limited degree, into the experience of premenstrual and menstrual suffering.

The women as well as the fathers, husbands and other relatives who sometimes wrote in their stead were unanimous: menstruation was an essential prerequisite for the preservation of a woman's health and its disorders were a major cause of disease. As to why this should be so, the letters confirm the frequent complaints of eighteenth- and nineteenth-century physicians: the women not only believed that menstruation got rid of superfluous blood or fluid but still held the "false and dangerous opinion", 92 as the physicians termed it, that the menstrual flow was "furnished by an acrid and poisonous humour, whose deleterious qualities harm the constitution, if it does not succeed in freeing itself from it" ${ }^{93}$ Except for times of pregnancy, an appropriately abundant menstrual flux at regular intervals was therefore much desired. Any delay, reduction or total "suppression" of the menstrual flow, on the other hand, aroused great concern and was quickly identified as the probable cause of any ensuing disease. Sick women eagerly expected their next period and were happy when a large quantity appeared, say "three very big spoonfuls", raising hopes for a decisive improvement. ${ }^{94}$

But menstruation was a blessing and a curse. It prevented and healed diseases but it also caused suffering in itself. The ambiguity was aptly expressed in the concurrent use of terms like "monthly purgation" or "succour of nature" along with expressions like "being out of order", the "female malady" or the "female disease". Some of the women who consulted the famous French accoucheur Mauquest de la Motte even presented themselves with words like "I am rather sick [malade]" when their monthlies were copious, or as just "a little sick" when they were less so..$^{95}$ Accordingly, early

\footnotetext{
${ }^{91}$ The following discussion is based on my current work on various collections of letter consultations written by lay people. For this paper I have used letters addressed to Étienne François Geoffroy (1672-1731), Bibliothèque Interuniversitaire de Médecine, Paris, MSS 5241-5245 (henceforth: BIUM), to S A Tissot (1728-1797), Bibliothèque Cantonale et Universitaire de Lausanne, Fonds Tissot (henceforth: FT), and to the founder of homoeopathy, Samuel Hahnemann (1755-1843), Institut für Geschichte der Medizin der Robert
}

Bosch Stiftung, Stuttgart (Hahnemannarchiv, henceforth: HA), Bestand B and C.

${ }^{92} \mathrm{P}$ N Glinel, Sur l'âge critique des femmes, MD thesis, Paris, Didot, 1818.

${ }_{93}$ Édouard de Massia, Âge critique chez la femme, Montpellier, Boehm, 1851, p. 19 (cit.); Fothergill, op. cit., note 63 above, p. 163.

${ }^{94}$ FT, letter from Mme du Neville, 15 Jan. 1774.

${ }^{95}$ Guillaume Mauquest de la Motte, Traité complet des accouchemens naturels, non naturels, et contre nature, Paris, L d'Houry, 1702, pp. 71-2. 
modern recipe books could somewhat paradoxically recommend various remedies "to bring about the female disease". ${ }^{96}$ Bridging the realms of health and disease, menstruation was similar to the "critical" evacuations of harmful matter via sweat, urine, faeces, etc. which were said to resolve most diseases and were frequently promoted by therapeutic means. It was a "crisis" bordering on the pathological but nevertheless essential for health.

Menstrual suffering was quite frequently mentioned in the letters. A characteristic complaint in the premenstrual phase were mood changes. They ranged from sadness and prostration to utmost irritability. The Marquise d'Aglie, for example, felt generally indisposed and had "nervous attacks", which were relieved by the menstrual flux. ${ }^{97}$ The periods of an English patient "announced" themselves with an increased "irritation of the nerves". ${ }^{98}$ Mood swings, which retrospectively, a couple of days later, were understood as having indicated the approach of the periods, can even be traced in medical diaries like those which homoeopathic patients were typically asked to keep. ${ }^{99}$ Thus, in July 1831, two days, as it turned out, before her "monthlies" set in, Antonie Volkmann felt highly "irritable". Painful fantasies tormented and frightened her so much that "the blood became very agitated", and she "could by no means sleep". A few months later, she felt again "extremely irritable", only to find two days later that her period had arrived. ${ }^{100}$

Feelings of heaviness, painful tension and swelling, suggestive of a premenstrual accumulation of matter or of vapours rising from it, were similarly common. One of Tissot's patients had pain and a "feeling of heaviness" eight days before her period. ${ }^{101}$ The Bavarian Electoress suffered from headache and a feeling of unease in the back and the whole body, hours before her period; a brief spell of dizzinesstraditionally a typical sign of congestion-disappeared when the blood flowed more abundantly. ${ }^{102}$ Similarly, Mme de Chastenay often had a feeling of tension in the head and eye troubles a few days before her periods. ${ }^{103}$ Nineteen-year-old Mlle Tillière, even worse, experienced frequent premenstrual convulsions which eventually extended over the whole menstrual period. They were accompanied by headaches, stomach-aches, dyspnoea and swollen legs. Only massive blood-letting brought some relief. $^{104}$

\footnotetext{
${ }^{96}$ An early example is in Sächsische Landesund Universitätsbibliothek Dresden, MS C 457 (c. fifteenth century), 'Aller handt sehr nützliches vnndt propierte Recept für Schwangere vnndt gebehrende Frawen', fols. 18v-19r: "Die weibliche Kranckheit zue pringen."

${ }^{97} \mathrm{FT}$, letter from the patient's husband, the Marquis d'Aglie, 6 Nov. 1776.

${ }^{98} \mathrm{FT}$, letter from the patient, 17 Dec. 1783 , illegible signature.

${ }^{99}$ Recent research shows significant differences in the outcome of retrospective and prospective subjective assessments of menstrual complaints; cf. Jessica McFarlane, et al., 'Mood fluctuations: women versus men and menstrual versus other
}

cycles', Psychology of Women Quarterly, 1988, 12: 201-23.

${ }^{100}$ Reinhard Hickmann, Das psorische Leiden der Antonie Volkmann. Edition und Kommentar einer Krankengeschichte aus Hahnemanns Krankenjournalen von 1819-1831, Heidelberg, Haug, 1996, pp. 352-92, 374 (cit.), 389.

${ }^{101}$ FT, letters from the patient, Mme Viton, and her husband, 25 March and 6 June 1775.

${ }^{102}$ Bayerische Staatsbibliothek Munich, 4 L.impr. n. MSS 57, printed calendar with manuscript entries on the Elector's family's state of health, presumably by their personal physician.

${ }^{103} \mathrm{FT}$, letter from the patient, 21 Feb. 1785.

${ }^{104}$ FT, letter from the patient, 1 March 1767. 
A particularly common and vexing complaint was the menstrual colics or "tranchées" as they were commonly called in contemporary French. ${ }^{105}$ The colics were not always linked specifically to the premenstrual phase. "Some belly pain, like when the periods begin" a German patient noted one day; a few days later she reported that bleeding had indeed begun. ${ }^{106}$ Short but violent were the premenstrual colics of a seventeen-year-old girl whom É F Geoffroy in Paris treated. ${ }^{107}$ In other cases we hear about "great back pains" and "colics" during the periods, ${ }^{108}$ especially, one woman complained, during the first ten to twelve hours. ${ }^{109}$ Forty-year-old Mme $\mathrm{Du}$ Neville even consulted specifically for her menstrual pains, which she could not describe better than "by telling you that they are exactly like those of a woman in labour". ${ }^{110}$ A 32-year-old maid servant was frequently forced to lie down, because her whole belly contracted, with a sensation of "pushing and pressing from down below"."11

Beyond the search for an adequate image to convey the nature of the colic to the distant physician, such expressions probably also reflected implicit notions of the nature of the menstrual evacuation. The bleeding seems to have been perceived as an active process but not necessarily as the kind of glandular secretion by a specialized tissue or organ which vitalist physiology envisaged. Rather, some of the letter consultations suggest a belief that the blood was collected in the uterine cavity itself, like in a vessel, to be then driven out by the active contraction of the uterus. In this light a certain degree of premenstrual but also of menstrual uterine pain would have appeared as the natural consequence of the muscular contraction involved. The pain was bound to increase when the blood lost its natural fluidity and became harder to expel, when it coagulated into clots or even came out in large lumps. It was particularly in these cases that the women compared menstrual heaviness and pain to the contractions and the bearing down in labour, to the impact of a child that "seeks to open a passage for itself". 112

Other patients again experienced the periodical deterioration of an underlying disorder, frequently with symptoms which could be taken as a direct evidence that superfluous blood and/or peccant matter was either accumulating premenstrually or only insufficiently evacuated via menstruation and therefore deposited elsewhere. Mme de Vury's “congestion" and "swelling" of neck and body, for example, increased "at the approach of the periods". ${ }^{113}$ Similarly, the knee tumour of a 33-year-old

${ }^{105}$ Jean Louis Baudelocque, L'art des accouchemens, Paris, Méquignon, 1781, vol. 1, pp. 102-3.

${ }^{106}$ HA B 33349, diary of Emma von Hedemann, entry for 18 Feb. 1835.

${ }^{107}$ BIUM MS 5245, fols. 263r-264v, unsigned letter, probably from a friend of the patient's family, 11 Nov. 1729.

${ }^{108}$ BIUM MS 5241, fols. 162r-165v, unsigned letter, possibly from the patient's physician, June 1729; FT, letter from Mme Ostervald, 29 Jan. 1784; FT, undated letter from the thirty-year-old Countess de Balon (?); HA B 34083, letter from a patient's husband, W Grosse, 1 Jan. 1834.
${ }^{109} \mathrm{FT}$, letter from the patient, Mme la présidente de Verthamon, 6 Jan. 1777.

${ }^{110} \mathrm{FT}$, letter from the patient, $15 \mathrm{Jan} .1774$.

${ }^{111}$ HA B 32250 Hahnemann's notes on a personal consultation by Christiane Rennicken, 1832; the German words "Zusammenklumpen des ganzen Bauches" connote contractions as well as some kind of a lump.

${ }^{112}$ FT, letters from Mme Viton and her husband, 25 March and 6 Sep. 1775.

${ }^{113} \mathrm{FT}$, letter from the patient, Mme de Vury, 2 Apr. 1774. 


\section{The Monthly Malady}

Benedictine nun grew in size with every menstruation, ${ }^{114}$ and the abdominal tumours of another patient became more painful. ${ }^{115}$ In one woman the agitation of the blood, the itching "between skin and flesh" and skin rashes increased at the time of her periods,- - both symptoms were closely linked to notions of corrupt or acrimonious humours ${ }^{116}$ - and so did the "vapours", dyspnoea, pains and cramps, ${ }^{117}$ or the posttraumatic headaches, convulsions and melancholy in others. ${ }^{118}$

The degree of the women's suffering varied. Some described it as so intense that they could hardly endure it. Mme Ostervald in Neufchâtel, for example, who was periodically subject to spasmodic vomiting, a terrible disgust of food, increased languor, and colicky pain before her menstruation, lived "always in apprehension of the next period". ${ }^{119}$ But in most cases, the symptoms were mentioned only because they contributed to a better understanding of those principal complaints which motivated the consultation. A degree of premenstrual and menstrual discomfort seems to have been so familiar, in fact, that some women explicitly made it a point that they did not experience "in the times of the periods and that which precedes them any kind of indisposition", ${ }^{20}$ or that they had not previously suffered from menstrual colics "like many other women experience them". ${ }^{121}$

For obvious reasons, patient letters reflect almost exclusively the menstrual experiences of middle- and upper-class women. For the majority of largely illiterate women, all we can rely on are occasional hints in the case histories of contemporary physicians, in court proceedings for infanticide, abortion and fornication and the like, and, with some reservations, in recipe books. ${ }^{122}$ These sources provide fairly clear evidence that lower-class women shared the conviction that menstruation cleansed the body from harmful impurities and not just from superfluous blood and perceived its disturbance as a serious threat. They hardly yield any information, however, on the more specific issue of premenstrual complaints. This changes only in the nineteenth century, when the first statistical surveys confirmed the high prevalence of premenstrual complaints also among the lower classes. Brierre de Boismont found in the 1830 s that 496 out of 654 ( 76 per cent) women he interviewedalmost all of them seem to have been poor hospital inmates-reported premenstrual or menstrual complaints, with pain and headaches topping the list. 45 per cent of lower abdominal, pelvic and lumbar complaints and at least 41 per cent of general

${ }^{114}$ BIUM MS 5244, fols. $130 \mathrm{r}-133$ r, letter from her physician, 28 June 1729.

${ }^{115}$ BIUM MS 5245, fols. 187r-188r, undated letter, possibly from a relative.

${ }^{116} \mathrm{FT}$, letter from the patient, 26 June 1793, illegible signature.

${ }^{117}$ BIUM 5241, undated letter from the patient's sister, Mme Doyen of Strasbourg.

${ }^{118}$ BIUM MS 5244, fols. 139r-140v, undated letter concerning an unnamed 22-year-old, probably written by the patient herself.

${ }^{119}$ FT, letter from the patient, 29 Jan. 1784; she also suffered from irregular bleeding between her periods, and was convinced that the menstrual blood loss contributed to her weakness.

\footnotetext{
${ }^{120} \mathrm{FT}$, undated letter from the patient, Mme de Chancrier(?).

${ }^{121}$ HA C 9,3, letter from Mme de Fontenay concerning her daughter.

${ }^{122} \mathrm{Cf}$. Barbara Duden, The woman beneath the skin: a doctor's patients in eighteenth-century Germany, Cambridge, MA, Harvard University Press, 1991; Crawford, op. cit., note 21 above; Ulinka Rublack, 'Pregnancy, childbirth and the female body in early modern Germany', Past and Present, 1996, 150: 84-110. Though recipe books are often somewhat mistakenly called "popular" they are primarily found among the literate middle and upper classes.
} 


\section{Michael Stolberg}

symptoms began before menstruation, often ending with its onset. ${ }^{123}$ In 1905, Maria Tobler's survey showed even higher figures, with 434 out of 756 (57.4 per cent) working-class women complaining specifically about premenstrual symptoms. In 326 cases (43.1 per cent) these included psychological troubles, a slightly higher figure even than the average of 42.0 per cent for the whole sample. ${ }^{124}$

\section{Conclusion}

The history of premenstrual somatic, emotional and behavioural disorder can be traced over hundreds, if not thousands of years. ${ }^{125}$ Some symptoms like abdominal pain or backaches and headaches appear remarkably constant, suggesting the possibility of a universal, biological basis. Others like fever or nervous irritability gained prominence primarily at specific times and thanks to specific models of menstruation and the human body. Throughout this history, however, the descriptions given by physicians and women alike fell well within the boundaries of modern definitions of the "premenstrual syndrome" which underlie Richardson's and Johnson's claim that PMS is specific and unique to modern Western industrial society. As I hope to have shown, it clearly is not. Undoubtedly, the experience and interpretation of premenstrual suffering was and is thoroughly shaped and framed by culture and society but in this sense any kind of physical or emotional experience and suffering is "culture-bound".

Neither does the history of premenstrual suffering across the centuries offer a particularly good example for the increasing "medicalization" of normal life events and the female body. Certainly, professional ambitions and disciplinary claim staking, for example by gynaecologists, psychiatrists and endocrinologists, and more recently the interests of the pharmaceutical industry contributed to the repeated reframing of such disorders. ${ }^{126}$ But they were described as very common already hundreds of years ago, with estimates reaching as high as 95 per cent of all menstruating women, and they prompted energetic therapeutic interventions, which in the eighteenth and nineteenth centuries, for example, included repeated blood-letting and opium. ${ }^{127}$ Furthermore, the ready acceptance of the new eighteenth-century paradigm of "nervous irritability" on the one hand and the tenacious adherence to cathartic

\footnotetext{
${ }^{123}$ Brierre de Boismont, op. cit., note 69 above, pp. $77-117$; in 80 cases with general symptoms no exact temporal relationship between them and the onset of menstruation was established. The class composition of the sample is not well identified but the study seems to have been done among the predominantly poor inmates of the Paris hospitals, where Brierre was working.

${ }^{124}$ Tobler, op. cit., note 88 above; the figure includes those whose symptoms continued during menstruation; Tobler distinguished working-class from upper-class women and from women without a profession; Tobler's figures for the "upper-class" patients did not differ significantly, except for the small group of women (71 out of
}

1020) whose well-being improved with menstruation: only 4 per cent of working-class women but a remarkable 30 per cent of upperclass women reported this positive experience.

${ }^{125}$ For an even earlier account of the signs of an approaching menstruation but possibly referring primarily to menarche, see Soranos of Ephesos, Maladies des femmes, French and Greek text, vol. 1, ed. Paul Burguière, Danielle Gourevitch and Yves Malinas, Paris, Les belles lettres, 1988, pp. 15-29.

${ }^{126} \mathrm{Cf}$. Oudshoorn, op. cit., note 83 above.

${ }^{127}$ Hamilton, op. cit., note 80 above, p. 131 . Fothergill, op. cit, note 63 above, p. 184; Merat, op. cit., note 60 above; Saucerotte, op. cit., note 56 above, p. 47. 


\section{The Monthly Malady}

notions of menstruation on the other suggest that women were quite capable of making their choices, resisting dominant medical theories when they did not suit them. ${ }^{128}$ We cannot even be sure, in fact, that medical interest in premenstrual suffering was not prompted by female complaints in the first place. As early as the sixteenth century, Giambattista Da Monte claimed that he knew women, "who are forced to lie down in bed, when this flux approaches", ${ }^{129}$ and, as we have seen, decades before "premenstrual tension" became an accepted medical term, countless women complained about the symptoms Frank later associated with it. Ironically, some physicians around 1900 even gave new credibility to the persistent female notion that menstruation "cleansed" the body. Though the notion of an actual "menotoxin" remained highly controversial, Tobler, for example, explained the premenstrual symptoms as the result of an intoxication with accumulating metabolic products. ${ }^{130}$

Last but not least, the story of PMS offers a salutary warning against a widespread tendency in current literary, cultural and historical studies to literally "read" the body and its disorders as if they presented a "text", a "message" like any other, as if they could be simply taken as an immediate expression or "representation" of certain values, preoccupations, interests or conflicts. Though it can undoubtedly lead to fascinating hypotheses and has opened fruitful new areas of research, there are serious problems with this approach.

First, even if we accept that at least some disorders directly "represent" certain values, conflicts, etc. the same symptom would have to convey quite different messages under different cultural, social and political circumstances. The premenstrual symptoms of middle- and upper-class women in the eighteenth and nineteenth centuries cannot reasonably be explained as a representation of the role conflict between motherhood and productive work - though they might suggest anger and protest against the self-restraint imposed by a rigidly formalized social life and the negation of female desires and self-expression. Careful contextualization is of paramount importance here.

Second, the history of PMS - as that of menopausal disorders ${ }^{131}$ - underlines the importance of understanding contemporary accounts within the framework of underlying physiological notions. In our case these are, in particular, changing concepts of menstruation and its role in the female body. From them the various premenstrual and menstrual complaints derived much of their significance, meaning and legitimacy. ${ }^{132}$ This is not to say that the history of premenstrual symptoms was just one of new scientific ideas and their dissemination among the population, and I hope my focus on these concepts has not created that impression. Contemporary

\footnotetext{
${ }^{128}$ Loudell F Snow and Shirley M Johnson, 'Modern day menstrual folklore', J. Am. med. Ass., 1977, 237: 2736-9; Yvonne Verdier, Façons de dire, façons de faire. La laveuse, la couturière, la cuisinière, Paris, Gallimard, 1979.

${ }^{129} \mathrm{Da}$ Monte, op. cit., note 32 above, p. 738.

${ }^{130}$ Tobler, op. cit., note 88 above, pp. 40-2.

${ }^{131}$ See Michael Stolberg, 'A woman's hell?

Medical perceptions of menopause in
}

preindustrial Europe', Bull. Hist. Med., 1999, 73: 404-28.

${ }^{132}$ A point well made by Gail Kern Paster, The body embarrassed: drama and the disciplines of shame in early modern England, Ithaca, Cornell University Press, 1993. 


\section{Michael Stolberg}

power structures and socio-economic change and, more particularly, issues of gender relations and female status undoubtedly did play an important part in this story. The point I want to make is that they figured primarily back-stage. Their impact on the perception of premenstrual disorders went largely via more general ideas about the differences between the sexes and the effects of class-specific life-style. And even more importantly, the emergence of fundamental new physiological concepts and paradigms like iatrochemistry, blood circulation or the rise of the nervous system, which decisively framed the perception of premenstrual disorder, was subject to a wide range of social and cultural influences, among which issues like gender relations or female role conflict did not necessarily play any major part at all.

Finally, the significance and dynamics of psychosomatic symptom choice as such are far from being resolved, even in current medical and psychological debate and within the context of our own culture. Few in modern Western culture would doubt that emotions can influence the body and bodily processes themselves and not just their perception and verbalization. But if the use of modern medical concepts in retrospective diagnosis has met with wide and well-founded scepticism, the same caution should presumably apply to the use of modern notions of somatization or somatic symbolization implicit in any attempt to "translate" symptoms into messages. Otherwise our interpretations are bound to remain highly speculative. When, for example, a childless woman, who in many years of marriage only had a miscarriage, likened her period pains to those of being in labour, ${ }^{133}$ the symbolism may appear almost tangible. But how are we to know whether we read this symbolic language correctly, when the perception of menstruation itself was so different from that of today? And on which basis can we decide between various potential meanings, when women with a very different life story describe very similar sensations? Mlle de Fontenay, for example, also developed severe menstrual colics (in addition to a very depressed mood) when her sister died from "chest disease" following two childbirths in the space of only eleven months, suggesting a horror of any pregnancy rather than a strong desire for it, as in the case above. ${ }^{134}$

It could indeed be argued that, more often than not, symptoms and illnesses do not express any "meaning" at all, ${ }^{135}$ that, we quite simply become sick and die, because we are of mortal flesh, with no other "message" than that. And even if we accept the notion and importance of somatization, we must take notice of culturalanthropological findings which show the modes and frequency of somatization to be highly contingent on the respective culture and society. ${ }^{136}$ The body is neither a passive piece of flesh into which the dominant discourse of ruling elites can freely inscribe its ideology, nor a timeless mirror in which the historian may conveniently follow the workings of the soul. 1774.

${ }^{133}$ FT, letter from Mme Du Neville, 15 Jan.

${ }^{134}$ HA C 9,3, letter from the patient's mother.

${ }^{135}$ Susan Sontag, Illness as metaphor, London, Allen Lane, 1979.

${ }^{136} \mathrm{Cf}$. Arthur and Joan Kleinman,

'Somatization: the interconnections in Chinese society among culture, depressive experiences, and meanings of pain', in A Kleinman and B Good (eds), Culture and depression: studies in the anthropology and cross-cultural psychiatry of affect and disorder, Berkeley, University of California Press, 1985, pp. 429-90. 